\title{
IMPLEMENTASI PEDOMAN KENDALI MUTU AUDIT-APARAT PENGAWASAN INTERN PEMERINTAH PADA INSPEKTORAT PROVINSI SULAWESI UTARA
}

\author{
Sendy J. Mewengkang \\ Linda Lambey \\ David P. E. Saerang
}

(smewengkang@yahoo.com)

\begin{abstract}
The purpose of this research is to know the Implementation of Audit Quality Control Internal Auditing of Government Apparatus (PKMA-APIP) at Inspectorate of North Sulawesi Province. Procedures in PKMA-APIP consist of Strategic Plan Design, Audit Plan, Audit Action Plan Program Design, Audit Supervision, Audit Process, Audit Report, Feedback on Audit Report and Human Resources they are intended to ensure APIP professionalism implementation in enhancing supervising role quality.

This study is a qualitative descriptive research. The result show that the implementation for audit quality control in the Inspectorate of North Sulawesi Province is not optimal and not appropriate perfectly. It is because the audit plan has not been implemented appropriate with PKMA-APIP, human resources are unqualified to fulfill existing workload, monitoring follow up results of the audit conducted by the unit performing the function of reporting is not maximized, unclear job description towards the unit managing administration and human resources, procedures provided in supporting the implementation of the tasks have not yet been implemented adequately and effectively to monitor the implementation of programs and activities (peer review). The monitor is to ensure and guarantee that the audit conducted by the Inspectorate of North Sulawesi Province meet the standard audit.
\end{abstract}

Keywords $\quad$ : Audit, Quality Control, Government Internal Auditors

\subsection{Latar Belakang Masalah}

\section{PENDAHULUAN}

Reformasi yang terjadi di Indonesia telah membawa perubahan besar salah satunya perubahan dalam tata kelola pemerintahan baik di pusat maupun di daerah. Perubahan ini menuntut konsekuensi dan tanggung jawab bagi penyelenggara pemerintah untuk melaksanakan tata kelola pemerintahan sesuai dengan prinsip dan aturan-aturan yang telah ditetapkan.

Menurut Peraturan Menteri Negara Pendayagunaan Aparatur Negara Nomor : Per/05/M.Pan/03/2008 Tentang Standar Audit Aparat Pengawasan Intern Pemerintah (SA-APIP) menyebutkan bahwa Pengawasan intern pemerintah merupakan fungsi manajemen yang penting dalam penyelenggaraan pemerintahan. Pengawasan intern atas penyelenggaraan pemerintahan diperlukan untuk mendorong terwujudnya good governance dan clean government. Dalam mewujudkannya, pengendalian mutu audit merupakan hal yang penting untuk memastikan pengawasan yang dilaksanakan berjalan maksimal serta meminimalisir kemungkinan penyimpangan yang terjadi selama proses audit berlangsung. APIP melakukan pengawasan atas kegiatan yang dilaksanakan oleh satuan/unit kerja dilingkungannya yang bertujuan sebagai pencegahan dan deteksi dini agar tidak terjadi penyimpangan dalam pengelolaan keuangan, maupun kekeliruan yang bisa mempengaruhi pencapaian tujuan, serta bertugas untuk mengawal berbagai program dan kegiatan dalam penyelenggaraan pemerintahan. Oleh karena itu, APIP dituntut untuk semakin meningkatkan mutu dan perannya sebagai upaya dalam pencapaian tujuan dan sasaran penyelenggaran pemerintahan yang telah ditetapkan. Sesuai dengan ketentuan Peraturan Pemerintah Nomor 41 Tahun 2007 tentang Organisasi Perangkat Daerah, Inspektorat merupakan unsur pengawas penyelenggaraan pemerintah daerah. Inspektorat Daerah mempunyai tugas melakukan 
pengawasan terhadap pelaksanaan urusan pemerintah daerah/provinsi, pelaksanaan pembinaan atas penyelenggara pemerintahan daerah kabupaten/kota dan pelaksanaan urusan pemerintahan di daerah kabupaten/kota. Inspektorat Provinsi Sulawesi Utara sebagai APIP di Pemerintah Provinsi Sulawesi Utara yang dibentuk Peraturan Gubernur Sulawesi Utara Nomor 8 Tahun 2008 merupakan unsur pengawas penyelenggaraan pemerintahan daerah memiliki peran dalam membantu Gubernur melakukan pengawasan terhadap penyelenggaraan pemerintahan daerah dan pengelolaan serta akuntabilitas keuangan dan aset daerah.

Untuk memastikan dan memberikan jaminan yang memadai apakah audit yang dilaksanakan telah sesuai dengan Standar Audit, Kementerian Negara Pendayagunaan Aparatur Negara dan Reformasi Birokrasi (KemenPAN dan RB) menetapkan Pedoman Kendali Mutu Audit-Aparat Pengawasan Intern Pemerintah (PKMA-APIP) melalui Peraturan Menteri Negara Pendayagunaan Aparatur Negara dan Reformasi Birokrasi (PermenPAN dan RB) Nomor 19 Tahun 2009 sebagai suatu prosedur dan reviu pengendalian yang harus dilakukan oleh setiap unit APIP yang meliputi kebijakan, prosedur dan program pengendalian pada lingkup kewajiban unit APIP. Terdapat delapan elemen yang diatur dalam PKMA-APIP yaitu Penyusunan Rencana Strategis, Pengendalian Mutu Perencanaan Audit APIP, Pengendalian Mutu Penyusunan Rencana dan Program Kerja Audit, Pengendalian Mutu Supervisi Audit, Pengendalian Mutu Pelaksanaan Audit, Pengendalian Mutu Pelaporan Audit, Pengendalian Mutu Tindak Lanjut Hasil Audit, dan Pengendalian Mutu Tata Usaha dan Sumber Daya Manusia. Delapan elemen ini adalah prosedur-prosedur yang digunakan untuk memastikan bahwa APIP telah memenuhi tanggung jawab profesionalnya.

Namun demikian walaupun berbagai standar serta pedoman telah ditetapkan untuk digunakan sebagai acuan dalam melaksanakan audit, hasil Audit Kinerja BPK Perwakilan Provinsi Sulut tahun 2013 antara lain menyebutkan bahwa Inspektorat Provinsi Sulut belum memiliki program kerja yang memadai dalam mendukung fungsi audit dan Reviu Laporan Keuangan. Demikian pula dengan Hasil Pemetaan yang dilakakukan BPKP pada tahun 2014 terkait dengan Tingkat Kapabilitas APIP yang diadopsi dari Internal Audit Capability Model (IA-CM), Inspektorat Provinsi Sulut masih berada pada level 2 yaitu level Infrastructure.

Dalam rangka mewujudkan praktik profesional audit intern secara seragam dan selaras sepenuhnya dengan standar audit serta memberikan advisory services untuk perbaikan governance process, risk management, control organisasi, Inspektorat Provinsi Sulawesi senantiasa harus menjaga kualitasnya. Wahyudiono (2000) mengungkapkan bahwa quality control atau Sistem Pengendalian Mutu merupakan suatu proses yang dilakukan untuk memastikan bahwa suatu output dapat memenuhi tujuan dan spesifikasi yang telah ditetapkan sebelumnya yang diwujudkan dengan mengunakan pedoman atau standar yang telah ditetapkan. Pentingnya pengendalian mutu dalam mewujudkan fungsi pengawasan yang memenuhi kriteria, berdayaguna, dan berhasilguna mendorong penulis melakukan penelitian dengan mengangkat judul "Implementasi Pedoman Kendali Mutu Audit-Aparat Pengawasan Intern Pemerintah pada Inspektorat Provinsi Sulawesi Utara".

\subsection{Teori Agensi}

\section{TINJAUAN PUSTAKA}

Teori keagenan (Agency theory) yang dikemukakan oleh (Michael C. Jensen dan William H. Meckling, 1976) menyatakan, "We define an agency relationship as a contract under which one or more persons (the principal(s)) engage another person (the agent) to perform some service on their behalf which involves delegating some decision making authority to the agent. If both parties to the relationship are utility maximizers there is good reason to believe that the agent will not always act in the best interests of the principal". Artinya hubungan agensi muncul pada saat satu atau lebih orang membuat perikatan melalui kontrak untuk melakukan beberapa layanan atas nama mereka yang melibatkan pendelegasian sebagian wewenang pengambilan keputusan kepada agen. Baik principal maupun agent memiliki kepentingan masing-masing sehingga menyebabkan terjadinya agency problem dimana principal tidak sepenuhnya percaya bahwa tindakan agent sepenuhnya 
untuk kepentingan organisasi. Pada sektor publik, pemerintah bertindak sebagai agen dan masyarakat sebagai principal. Pemerintah sebagai pengguna anggaran publik harus mempertanggungjawabkan akuntabilitasnya kepada masyarakat. Besarnya tanggungjawab yang diemban pemerintah untuk mengelola anggaran dan keuangan negara/daerah memerlukan pengawasan, pengawalan dan pengendalian. Disitulah APIP muncul berperan sebagai pihak yang melakukan pengawasan terhadap segala aktivitas yang dilakukan oleh pemerintah. Organisasi APIP harus menetapkan persyaratan kualitas dalam upaya membangun fungsi pengawasan yang kredibel dan dapat menjamin akuntabilitas penyelenggaraan pemerintahan. Persyaratan kualitas tersebut harus dipedomani, dipatuhi dan dilaksanakan dalam mewujudkan pengawasan yang efektif, efisien, berdayaguna dan berhasilguna.

\subsection{Teori Peran}

Peran merupakan aspek dinamis kedudukan (status), apabila seseorang melaksanakan hal dan kewajibannya sesuai dengan kedudukanya, maka ia menjalankan suatu peranan (Soekanto, 2002). Menurut Horton dan Hunt (1993) peran adalah perilaku yang diharapkan dari seseorang yang memiliki suatu status. Berbagai peran yang yang tergabung dan terkait pada satu status ini disebut perangkat peran (role set). Teori peran menggambarkan interaksi sosial dalam terminologi aktor-aktor yang bermain sesuai dengan perannya masing-masing. Seseorang yang mempunyai peran tertentu diharapkan agar berperilaku sesuai dengan perannya tersebut. Dalam kaitannya dengan penelitian ini, pemerintah dan masyarakat masuk dalam satu perangkat peran (role set) pemerintah sebagai pelayan publik yaitu bertanggungjawab untuk mewujudkan kesejahteraan rakyatnya. APIP sebagai bagian dari pemerintahan, menjalankan perannya sebagai fungsi pengawasan yang menjamin akuntabilitas penyelenggaraan pemerintahan. Sekuat dan sesempurna sistem yang dibangun tidak akan berhasil tanpa dukungan serta komitmen dari masing-masing peran dalam unsur pemerintahan.

\subsection{Auditing}

Arens, Elder dan Beasley (2010) mendefinisikan auditing sebagai berikut: "Auditing is the accumulation and evaluation of evidence about information to determine and report on the degree of correspondence betweeen the information and establish criteria. Auditing should be done by a competent, independent person". Artinya auditing adalah suatu proses pengumpulan dan pengevaluasian bukti tentang informasi yang dapat diukur mengenai suatu entitas yang dilakukan oleh seorang yang kompeten dan independen untuk melaporkan kesesuaian informasi dengan kriteria yang telah ditetapkan. Auditing berkaitan erat dengan akuntabilitas dan atestasi. Akuntabilitas berkaitan dengan kewajiban pihak dalam organisasi untuk melaporkan pertanggungjawabannya kepada pihak dengan kewenangan lebih tinggi. Untuk menjamin keandalan informasi dalam laporan akuntabilitas tersebut, dibutuhkan pihak yang independen untuk memberikan atestasi atas informasi tersebut. Menurut Mulyadi (2002), orang atau kelompok orang yang melaksanakan audit dapat dikelompokkan menjadi tiga golongan yaitu, Auditor Independen, Auditor Pemerintah, dan Auditor Intern. Audit intern memiliki peran sebagai mata dan telinga manajemen dalam organisasi. Audit intern adalah audit yang dilakukan oleh pihak dari dalam organisasi auditee. Audit intern dilaksanakan dalam rangka pelaksanaan fungsi pengawasan dalam manajemen. Dalam Modul Pembentukan Auditor Ahli (BPKP, 2009), audit intern pemerintah diklasifikasikan atas, Audit Keuangan, Audit Kinerja/Audit Operasional, dan Audit dengan Tujuan Tertentu

\subsection{Standar Audit Intern Pemerintah}

Standar Audit adalah kriteria atau ukuran mutu minimal untuk melakukan kegiatan audit intern yang wajib dipedomani oleh auditor intern pemerintah Indonesia. Standar Audit ditetapkan sebagaimana yang diamanatkan dalam pasal 53 Peraturan Pemerintah Republik Indonesia Nomor 60 Tahun 2008 tentang Sistem Pengendalian Intern Pemerintah. Standar Audit Intern Pemerintah 
(SAIPI) merupakan Standar Audit terbaru yang dikeluarkan oleh Asosiasi Audit Intern Pemerintah Indonesia pada tahun 2013 yang mengacu pada pedoman yang ditetapkan oleh pemerintah yaitu Peraturan Menteri Negara Pendayagunaan Aparatur Negara Nomor: PER/05/M.PAN/03/2008 tanggal 31 Maret 2008 tentang Standar Audit Aparat Pengawasan Intern Pemerintah (SA-APIP). Standar Audit ini mengatur mengenai kegiatan audit intern yang dapat dilakukan oleh auditor dan pimpinan APIP sesuai dengan mandat serta kedudukan, tugas, dan fungsi masing-masing meliputi Audit terhadap Aspek Keuangan Tertentu, Audit Kinerja, Audit Dengan Tujuan Tertentu, Evaluasi, Reviu, Pemantauan, serta Pemberian Jasa Konsultansi (consulting activities).

\subsection{Pengendalian Mutu Audit}

Menurut Akmal (2007) dikutip Sadono (2010), perlu adanya pemeriksaan intern yang dapat memberikan manfaat bagi pencapaian tujuan organisasi dan dipatuhinya standar profesi dan kode etik dalam kegiatan pemeriksaan merupakan hal yang menjadikan pengendalian mutu atau program jaminan kualitas menjadi penting. Kualitas audit mengacu pada pada standar dan aturan yang memuat kriteria atau ukuran mutu pelaksanaan dan juga tahapan prosedur yang yang harus dipatuhi. Pengendalian kualitas audit bagi manajemen akan menjadi suatu nilai tambah untuk menjaga dan meningkatkan kepercayaan unit pengawasan (untuk audit intern) terutama masyarakat. Pengendalian ini wajib dilakukan manajemen demi mempertahankan dan meningkatkan hasil audit.

\subsection{Hubungan Standar Audit dan Pengendalian Mutu Audit}

Menuru Arens, Elder dan Beasley (2015), Pengendalian mutu terdiri dari metode-metode yang digunakan untu memastikan bahwa kantor itu memenuhi tanggungjawab profesionalnya. Pengendalian mutu berkaitan erat tetapi berbeda dengan Standar Auditing. APIP harus mendokumentasikan kebijakan dan prosedur pengendalian mutunya. Untuk memastikan bahwa prinsip-prinsip dalam standar auditing diikuti pada setiap audit, APIP mengikuti prosedur-prosedur pengendalian mutu yang membantu memenuhi standar-standar tersebut secara konsisten. APIP harus mendokumentasikan kebijakan dan prosedur pengendalian mutunya Karena itu pengendalian mutu ditetapkan untuk pelaksanaan kegiatan APIP secara keseluruhan, sedangkan standar auditing diterapkan pada setiap penugasan.

\subsection{Penelitian Terdahulu}

Penelitian terdahulu yang menjadi pembanding dengan penelitian ini antara lain:

1. Penelitian oleh Lukito Fauji, Made Sudarma, M. Achsin (2015) mengenai Penerapan Sistem Pengendalian Mutu (SPM) Dalam Meningkatkan Kualitas Audit. Tujuan penelitian ini yaitu menguji pengaruh simultan, parsial, dan pengaruh dominan variabel penerapan Sistem Pengendalian Mutu (SPM) Kantor Akuntan Publik (KAP) terhadap Kualitas Audit. Populasi penelitian adalah auditor dan staf auditor KAP Malang berjumlah 76 orang. Metode analisis digunakan regresi linier berganda, pengujian hipotesis F-test, t-test dan variabel berpengaruh dominan berdasarkan standardized coefficient beta $(\beta)$. Hasil yang diperoleh dari penelitian ini, yaitu variabel SPM berpengaruh simultan terhadap kualitas audit. Independensi, penugasan personal, konsultasi, dan supervisi berpengaruh parsial terhadap kualitas audit, sedangkan pemekerjaan, pengembangan profesional, promosi, penerimaan keberlanjutan klien, dan inspeksi tidak berpengaruh parsial terhadap kualitas audit. Penugasan personal adalah variabel berpengaruh dominan terhadap kualitas audit.

2. Penelitian oleh Dona Meilisa Hasbara (2012) tentang Usaha Peningkatan Kualitas Audit yang dilakukan oleh Badan Pemeriksa Keuangan Republik Indonesia (BPK-RI). Tujuan penelitian ini yaitu untuk mengetahui pedoman ASOSAI dan EUROSAI dalam pengendalian kualitas audit dan pemerolehan keyakinan kualitas audit, mengetahui Sistem Pengendalian Mutu (SPM) dan Sistem Pemerolehan Keyakinan Mutu (SPKM) BPK-RI, dan mengetahui perbandingan Pengendalian Mutu dan pemerolehan keyakinan mutu yang terdapat dalam pedoman QA in Financial Audit ASOSAI dengan yang terdapat dalam petunjuk pelaksanaan SPKM BPK. 
Dengan Metode penelitian kualitatif yang bersifat deskriptif komparatif analitik, pengumpulan data melalui Observasi, kuisioner checklist, dan Penelitian Kepustakaan. Dengan hasil Penelitian BPK-RI meningkatkan kualitas audit dengan membentuk Sistem Pengendalian Mutu (SPM) untuk memperoleh keyakinan memadai bahwa pelaksananya mematuhi ketentuan peruandangundangan, standar pemeriksaan, serta laporan yang dihasilkan sesuai dengan kondisi yang ditemukan. Perbedaan pengendalian mutu BPK dengan ASOSAI terletak pada reviu pemeriksaan, Dalam pengendalian mutu ASOSAI yang melakukan pre-issueance review adalah tim quality assurance reviu selain dari tim intern audit itu sendiri. dengan begitu ASOSAI lebih independen dalam melakukan pre-issuance review dibanding BPK.

3. Penelitian oleh Bayu Dewanto Sadono (2010) dengan judul Analisis Pengendalian Mutu Audit pada Inspektorat Kementerian Energi dan Sumber Daya Mineral (Studi Kasus: Penerapan Pedoman Kendali Mutu Audit-Aparat Pengawasan Intern Pemerintah) menggunakan metode kualitatif deskriptif untuk memperoleh gambaran seutuhnya mengenai penerapan Pedoman Kendali Mutu Audit-Aparat Pengawas Intern Pemerintah yang ada di Inspektorat Jenderal Kementerian ESDM. Pengumpulan Data diperoleh melalui Observasi partisipatif moderate, wawancara tak berstruktur dan Penelitian Kepustakaan. Hasil yang diperoleh dari penelitian ini bahwa: (1) Top Management dan para auditor belum mempertimbangkan secara baik resiko dari praktik pengendalian mutu audit di lingkungan Itjen KESDM selama ini; (2) Belum disediakan prosedur mengenai pengendalian mutu audit; (3) Kertas Kerja Audit belum dipersiapkan dengan baik; dan (4) Belum adanya pedoman Reviu Jaminan Mutu atas hasil audit.

\section{KERANGKA KONSEPTUAL}

Berdasarkan rumusan masalah yang telah ditetapkan, pertanyaan spesifik yang dijadikan sebagai pertanyaan riset adalah:

1. Apakah Pedoman Kendali Mutu Audit-APIP di Inspektorat Provinsi Sulut telah diimplementasikan secara optimal?

2. Apa penyebab ataupun kendala yang dihadapi dalam mengimplementasikan Pedoman Kendali Mutu Audit-APIP di Inspektorat Provinsi Sulawesi Utara?

Setelah uraian dalam proses membangun pertanyaan riset diatas, langkah berikut adalah membangun proposisi (hipotesis teori). Proposisi pertama adalah Pedoman Kendali Mutu AuditAPIP merupakan suatu prosedur dan reviu pengendalian yang disusun dan ditetapkan sebagai acuan bagi lembaga pengawasan internal dalam melaksanakan fungsi pengawasannya. Proposisi kedua adalah Dalam upaya untuk mengendalikan kualitas pengawasan, Pedoman Kendali Mutu AuditAPIP harus dilaksanakan dengan optimal. Berdasarkan rumusan masalah, pertanyaan riset dan proposisi yang telah dibangun, maka model analisis penelitian ini dapat digambarkan sebagai berikut: 


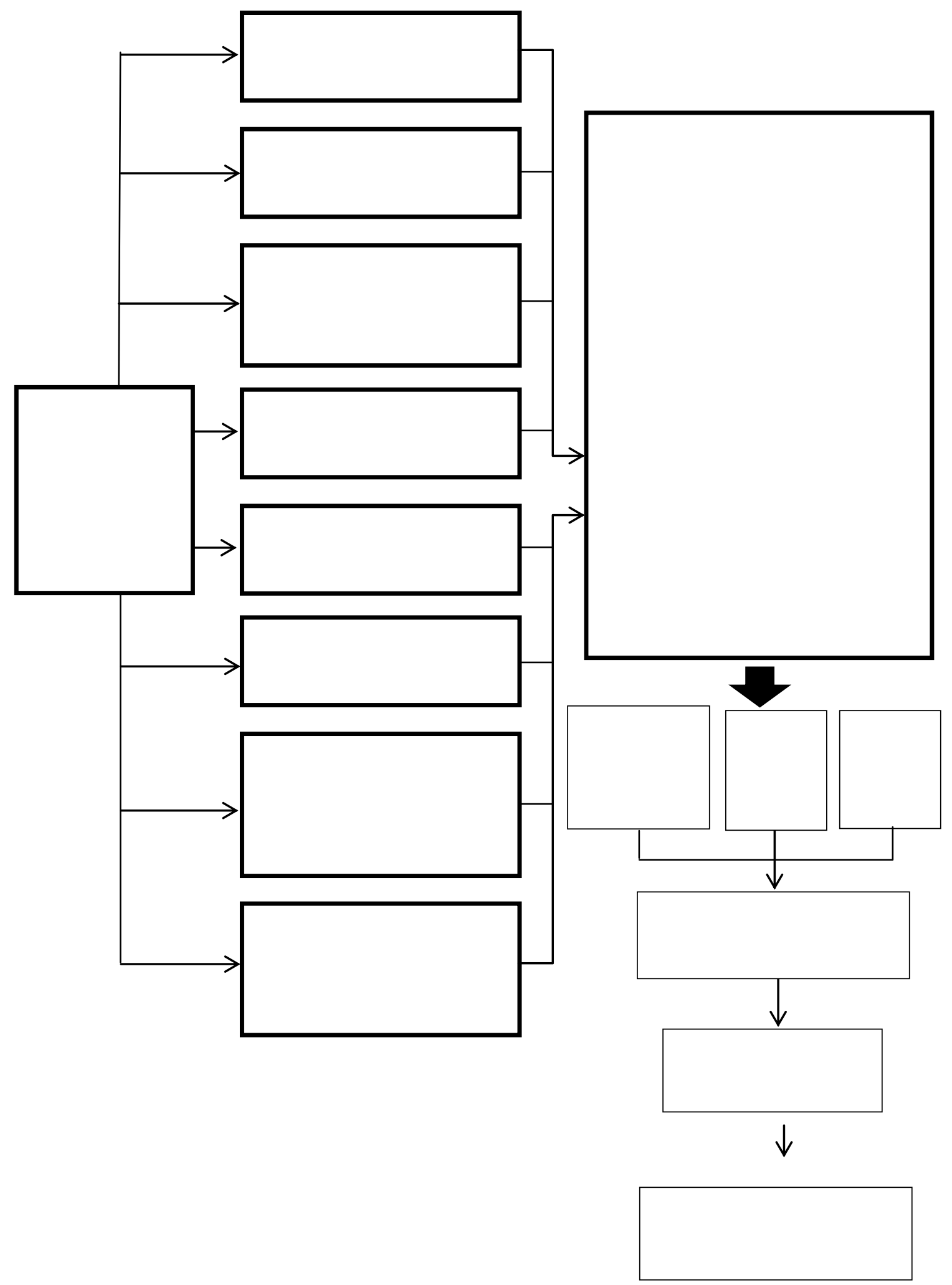




\section{METODE PENELITIAN}

Penelitian ini adalah jenis penelitian kualitatif deskriptif. Penelitian kualitaitif adalah prosedur penelitian yang menghasilkan data deskriptif berupa kata-kata tertulis atau lisan dari orang-orang dan perilaku yang dapat diamati (Bogdan dan Taylor, 1975). Penelitian kualitatif berhubungan dengan ide, persepsi, pendapat, atau kepercayaan orang yang diteliti, kesemuanya tidak dapat diukur dengan angka yang bertujuan memperoleh gambaran seutuhnya mengenai suatu hal menurut pandangan manusia yang diteliti (Djam'an dan Komariah, 2013). Pendekatan kualitatif dipandang sesuai untuk penelitian ini karena untuk memperoleh gambaran mengenai prinsip-prinsip umum atau pola-pola yang berlaku umum dengan kenyataan yang terjadi dalam lokasi penelitian. Topik yang diangkat ini membutuhkan analisa berdasarkan keadaan/fakta/fenomena alamiah dan tidak dapat diukur dengan angka.

Penelitian ini akan dilakukan pada Inspektorat yang terletak di Provinsi Sulawesi Utara yang melakukan fungsi pengawasan pada 46 (empat puluh enam) Satuan Kerja Perangkat Daerah di Provinsi Sulawesi Utara dan 15 (lima belas) Kabupaten/Kota yang tersebar diseluruh wilayah Provinsi Sulawesi Utara, Waktu penelitian dilakukan selama bulan Juni-Agustus 2016.

Instrumen penelitian yang dipakai dalam penelitian ini adalah wawancara (dengan bantuan alat rekam, alat tulis) dan observasi di lingkungan Inspektorat Provinsi Sulawesi Utara serta studi dokumentasi untuk memperoleh data melalui dokumen/arsip SKPD dan studi kepustakaan melalui buku-buku ilmiah, jurnal, tesis, peraturan perundang-undangan serta referensi lainnya yang berkaitan dengan objek yang diteliti.

Analisis data akan dilakukan dengan menggunakan analisis isi (content analysis) kualitatif. Analisis isi adalah metode penelitian untuk penafsiran subjektif dari isi teks data melalui proses klasifikasi sistematis pengkodean dan mengidentifikasi tema atau pola (Hsieh \& Shannon, 2005). Analisis isi berfokus pada karakteristik bahasa sebagai komunikasi dengan memperhatikan isi atau arti kontekstual dari teks tersebut (Budd, Thorp, \& Donohew, 1967; Lindkvist, 1981; McTavish \& Pirro, 1990; Tesch, 1990). Menurut Hsich \& Shannon (2005). Analisis isi terdiri atas tiga pendekatan yaitu, (1) Conventional, dimana kategori pengkodean berasal langsung dari data teks, (2) Directed, yaitu analisis dimulai dengan suatu teori atau temuan penelitian yang relevan sebagai pedoman untuk kode awal, (3) Summative dimana analisis isi yang melibatkan penghitungan dari perbandingan, biasanya kata kunci atau konten diikuti interpretasi dari konteks yang mendasari. Penelitian ini menggunakan pendekatan directed analisis isi karena melalui pendekatan ini peneliti memiliki prediksi mengenai variabel, sehingga membantu dalam menentukan skema pengkodean/kategorisasi awal serta hubungan antara kode/kategori.

Proses analisis data, dalam penelitian ini proses analisis data menggunakan tahapan yang dikemukakan oleh Miles \& Huberman (dalam Moleong, 2006) yaitu:

1. Reduksi Data; Data yang diperoleh diidentifikasi adanya satuan yaitu bagian terkecil yang ditemukan dalam data yang memiliki makna bila dikaitkan dengan fokus dan masalah penelitian. Data yang diperoleh dari dari hasil wawancara cukup banyak, kompleks, dan tidak langsung fokus pada topik penelitian. Karena itu dibutuhkan proses reduksi data untuk memilih satuan data yang memiliki makna sesuai dengan fokus penelitian.

2. Kategorisasi; Data yang sudah diidentifikasi tersebut kemudian dikategorisasi dengan memilahmilah setiap satuan ke dalam bagian-bagian yang memiliki kesamaan. Setiap kategori yang memiliki kesamaan makna tersebut diberi kode atau nama. Penamaan tiap kategori didasarkan pada makna yang terkandung pada setiap kalimat atau paragraf yang dikategorisasikan berdasarkan elemen-elemen dalam Pedoman Kendali Mutu Audit-APIP yang menjadi fokus dalam penelitian ini. Kategorisasi dilakukan dengan memberikan warna tertentu pada kalimat atau paragraf yang memiliki kesamaan makna, selanjutnya disamping kalimat atau paragraf tersebut diberikan nama kategori.

3. Sintesisasi; Mensintesiskan yaitu mencari keterkaitan antara satu kategori dengan kategori lainnya. Setelah kategorisasi data dengan memberikan kode atau nama pada setiap kalimat atau paragraf, kemudian dilakukan sintesisasi dengan mengaitkan setiap kutipan kalimat atau paragraf 
yang memiki warna yang sama. Pemberian warna dalam tiap kategorisasi memudahkan dalam melakukan sintesisasi.

4. Penarikan kesimpulan; Dari setiap kutipan yang telah disatukan, akan dirumuskan uraian analitis serta pernyataan yang proporsional berdasarkan data yang diperoleh sehingga dapat ditarik suatu kesimpulan.

\subsection{Penyusunan Rencana Strategis}

\section{ANALISIS DAN PEMBAHASAN HASIL PENELITIAN}

Pearce dan Robinson (2000) mendefinisikan perencanaan strategis sebagai kumpulan keputusan dan tindakan yang menghasilkan formulasi dan implementasi dari rencana yang dirancang untuk mencapai tujuan suatu perusahaan. Rencana strategis sekurang-kurangnya berisi visi, misi, tujuan, strategi, program dan kegiatan APIP selama lima tahun. Dalam PKMA-APIP, pedoman penyusunan rencana strategis dimaksudkan untuk memberikan panduan bagi APIP dalam menetapkan visi, misi, tujuan, sasaran, strategi, program dan kegiatan yang merupakan rujukan pelaksanaan kegiatan APIP dan agar auditee dapat mengetahui visi, misi, dan tujuan serta kewenangan dan tanggung jawab APIP. Tujuannya adalah agar APIP mempunyai rencana strategis yang akan dipergunakan sebagai dasar kegiatan pengawasan dan keberadaan APIP diketahui serta dipahami oleh auditee.

Penyusunan rencana strategis yang dilaksanakan di IPROV SULUT telah sesuai dengan prosedur penyusunan rencana strategis dalam PKMA-APIP yang menghasilkan visi dan misi Inspektorat yang akan digunakan 5 (lima) tahun kedepan dimana Visinya yaitu "Terwujudnya Tata Kelola Pemerintahan yang Baik dan Bersih menuju Sulawesi Utara Hebat melalui Pengawasan yang Terpercaya" kemudian dalam rangka pencapaian visi, Inspektorat Sulawesi Utara memiliki misi sebagai berikut:

1) Mendorong terciptanya penyelenggaraan pemerintahan yang baik dan bersih;

2) Meningkatkan kapabilitas Inspektorat yang handal.

Penyusunan rencana strategis di ITPROV SULUT dilakukan secara partisipatif dan demokratis, melibatkan top management untuk menyumbangkan ide, saran, dan masukkan, serta disusun berdasarkan Peraturan Menteri Dalam Negeri Nomor 54 Tahun 2010 tentang Tahapan, Tatacara Penyusunan, Pengendalian, dan Evaluasi Pelaksanaan Rencana Pembangunan Daerah. Untuk penyusunan pernyataan visi, misi, dan tujuan serta kewenangan dan tanggung jawab dilakukan setelah rencana strategis disahkan oleh Gubernur.

\subsection{Perencanaan Audit}

Dengan kewenangan yang diberikan untuk melaksanakan pengawasan dilingkungan Pemerintah Provinsi Sulawesi Utara diperlukan Perencanaan audit yang lengkap dan tepat berdasarkan ukuran resiko masing-masing auditee. Arens et al (2015) menjelaskan, tujuan utama dari perencanaan audit adalah memahami bisnis dan industri klien yang akan digunakan untuk menilai resiko audit yang dapat diterima, resiko bisnis klien, dan resiko salah saji yang material dalam laporan keuangan. Demikian juga dalam Standar Audit Intern Pemerintah Indonesia (SAIPI, 2013) seksi 3010 paragraf 03 menjelaskan, penentuan prioritas kegiatan audit intern didasarkan pada evaluasi/penilaian risiko yang dilakukan oleh APIP. Hal ini mengindikasikan bahwa intensitas audit yang akan dilakukan terhadap auditee yang memiliki ukuran resiko tinggi akan berbeda dengan auditee yang memiliki ukuran resiko lebih rendah. Dalam PKMA-APIP, tujuan perencanaan audit adalah untuk memberikan panduan bagi APIP dalam menentukan objek audit, tujuan audit, tenaga pengawas, waktu audit, anggaran atau biaya perjalanan dan hasil audit untuk satu tahun anggaran, serta memastikan ukuran bagi pencapaian kinerja APIP.

Dari Hasil uraian analisis diketahui bahwa fungsi perencanaan di ITPROV SULUT tidak menetapkan besaran resiko untuk seluruh auditeenya, tidak membuat peta audit, tidak membuat rencana audit jangka menengah lima tahunan, dan PKPT yang disusun tidak memuat informasi yang lengkap dan terperinci. Untuk menilai secara memadai risiko salah saji yang material, auditor 
harus memahami industri bisnis klien. Pemahaman ini dapat membantu auditor mengidentifikasi risiko bisnis yang signifikan yang dihadapi oleh klien (Arens et al, 2015). Hal ini menegaskan bahwa menetapkan besaran resiko adalah penting dilaksanakan guna menentukan ukuran resiko yang dimiliki setiap auditee sehingga mempermudah dalam menentukan frekuensi audit yang akan dilakukan terhadap setiap auditee. Selanjutnya besaran resiko yang telah ditetapkan dimuat dalam peta audit. Karena jika besaran resiko ditetapkan dan peta audit dibuat maka secara otomatis akan memudahkan dalam menyusun rencana audit jangka menengah lima tahunan dan PKPT, dimana setiap SKPD akan memiliki frekuensi audit yang berbeda, persiapan tim audit lebih maksimal, dan penetapan waktu pelaksanaan audit akan lebih tepat.

\subsection{Penyusunan Rencana dan Program Kerja Audit}

Penyusunan rencana dan program kerja audit yang dimaksud dalam tahapan ini adalah proses perencanaan yang dilakukan tim audit sebelum melaksanakan tugas audit yang bertujuan untuk memberikan panduan bagi aparat pengawas dalam melaksanakan kegiatan audit. Standar Profesi Audit Internal (2004) menyatakan, dalam merencanakan penugasan, auditor internal harus mempertimbangkan sasaran penugasan, ruang lingkup penugasan, alokasi sumber daya penugasan, serta program kerja penugasan. Hal ini menegaskan bahwa aparat pengawas harus mengembangkan dan mendokumentasikan rencana untuk setiap penugasan, termasuk tujuan, ruang lingkup, waktu, dan alokasi sumber daya penugasan.

Berdasarkan hasil analisis diketahui bahwa ITPROV SULUT telah menyusun dan mendokumentasikan rencana untuk setiap penugasan, termasuk sasaran, ruang lingkup, waktu, dan metodologi audit yang akan digunakan melalui dokumen persiapan penugasan yang harus disiapkan oleh ketua tim yang dibantu tim auditnya meliputi routing slip, review sheet konsep penugasan, kartu penugasan, anggaran waktu pemeriksaan, konsep surat tugas, dan konsep surat pemberitahuan kepada SKPD atau kabupaten/kota yang akan diaudit, serta menyusun program kerja audit.

Perbedaan dalam penyusunan rencana dan program kerja audit yang dilaksanakan di ITPROV SULUT hanya pada fungsi/oknum yang seharusnya melaksanakan tugas tersebut. Hal ini disebabkan karena ITPROV SULUT belum memiliki pengendali mutu yang bertugas menunjuk tim yang akan melaksanakan tugas audit sehingga Sekretaris bersama Inspektur dilibatkan dalam penunjukkan tim audit dengan tujuan komposisi tim audit yang akan ditugaskan melaksanakan audit benar-benar seimbang. Dalam Modul Perencanaan Penugasan Audit (BPKP, 2011), menjelaskan jika dalam suatu instansi APIP tidak memilki pengendali mutu maka pimpinan APIP melekat tugasnya sebagai pengendali mutu. Keterbatasan sumber daya tidak dapat dijadikan alasan untuk tidak memenuhi Standar Audit. Selanjutnya laporan mingguan perencanaan audit tidak dibuat tetapi hanya didokumentasikan dalam review sheet konsep penugasan dan karena waktu penyusunan rencana dan program kerja audit di ITPROV SULUT biasanya hanya berkisar 2-3 hari yang jumlah hari tersebut sudah masuk dalam hari penugasan. Kemudian sesuai dengan SOP Pelaksanaan Pemeriksaan, Koordinasi dengan auditee dilakukan pada saat pelaksanaan audit.

\subsection{Supervisi Audit}

Supervisi harus dilakukan pada seluruh tahapan audit untuk membantu penyusunan rencana audit yang efisien dan efektif, untuk dapat mengoreksi jika terjadi kesalahan atau terdapatnya kondisi yang berubah dan memberikan arahan audit yang lebih baik serta tepat. Menurut Rue dan Byars (1999) dikutip oleh Boiman (2013) Supervisi adalah proses kegiatan mengawasi untuk membimbing secara langsung pelaksanaan program kerja atau tugas yang diselengggarakan oleh para pelaksana. Dimana sasaran supervisi adalah para pelaksana yang mengerjakan tugas atau pekerjaannya yang bersifat membibing dan mengarahkan agar program kerja atau tugas yang dilaksanakan berhasil.

Dari hasil analisis diketahui bahwa supervisi audit telah dilaksanakan di ITPROV SULUT mulai dari tahap perencanaan penugasan audit, pelaksanaan audit, sampai pada tahap pelaporan audit. Perbedaan dalam pelaksanaan supervisi audit di ITPROV SULUT dengan PKMA-APIP 
adalah supervisi ketua tim terhadap anggota tim yang belum konsisten, serta fungsi/oknum yang seharusnya melaksanakan supervisi dimana supervisi oleh pengendali teknis dilaksanakan oleh pengawas (Irban) dan supervisi oleh pengendali mutu dilaksanakan oleh pembantu penanggungjawab (Sekretaris). Supervisi ditingkat ketua tim belum sepenuhnya konsisten karena kurangnya sikap profesional yang dimiliki oleh sebagian ketua tim pada saat penugasan audit sementara berlangsung. Seharusnya seluruh aparat pengawas yang ditugaskan sebagai ketua tim harus memiliki sikap profesional serta benar-benar memahami fungsi dan tanggungjawab profesionalnya yaitu salah satunya dalam setiap kesempatan selama pekerjaan audit berlangsung melakukan review kertas kerja audit (KKA) yang dibuat anggota tim. Dalam Rahma (2003) dikutip oleh Boiman et al (2013) menjelaskan bahwa supervisor yang memimpin secara efektif adalah supervisor yang memberikan model untuk diteladani, yang memotivasi sehingga menimbulkan semangat kerja. Hal ini menegaskan bahwa aparat pengawas yang ditugaskan sebagai ketua tim harus memiliki integritas, bersikap profesional serta memberikan teladan kepada anggota timnya dengan bertanggungjawab melaksanakan seluruh tugas dan tanggungjawab yang dipercayakan oleh pimpinan salah satunya yaitu melakukan supervisi yang terus menerus dalam menjamin pelaksanaan penugasan audit.

Penyebab fungsi/oknum yang seharusnya melaksanakan supervisi dimana supervisi oleh pengendali teknis dilaksanakan oleh pengawas (Irban) dan supervisi oleh pengendali mutu dilaksanakan oleh pembantu penanggungjawab (Sekretaris) karena aparat pengawas yang dimiliki ITPROV SULUT belum memadai atau masih kurang, khususnya untuk jabatan auditor. Jabatan pengendali teknis dan pengendali mutu berada dalam jenjang jabatan auditor Dalam Modul Perencanaan Penugasan Audit (BPKP, 2011) menjelaskan jika dalam suatu instansi APIP tidak memilki pengendali mutu maka pimpinan APIP melekat tugasnya sebagai pengendali mutu. Begitupun dengan jabatan pengendali teknis, menurut Artherthon (2003) pendelegasian adalah mempercayakan wewenang dan tanggung jawab kepada orang lain untuk menyelesaikan suatu tugas yang didefinisikan dengan jelas dan disetujui dibawah pengawasan supervisor.

\subsection{Pelaksanaan Audit}

Pelaksanaan audit merupakan bagian terpenting dari keseluruhan tugas audit. Menurut Standar Profesi Audit Internal (2004) dalam melaksanakan audit, auditor internal harus mengidentifikasi informasi, menganalisis, mengevaluasi, dan mendokumentasikan informasi yang memadai untuk mencapai tujuan penugasan. Pelaksanaan audit harus sesuai dengan rencana audit, sesuai dengan program audit, sesuai dengan standar audit, terdokumentasi dengan lengkap, rapi, dan jelas untuk menjamin pelaksanaan audit mempunyai mutu yang tinggi. Ketua tim dianggap paling berpengaruh dan memiliki peran yang penting dalam jalannya pelaksanaan audit, karena ketua tim yang akan mengkoordinasikan anggota tim dalam mencapai tujuan audit, mengkomunikasikan kerja audit dengan pengendali teknis dan pengendali mutu, maupun berkomunikasi dengan dengan auditee mengenai pekerjaan audit.

Dari hasil analisis diketahui bahwa Pelaksanaan Audit di ITPROV SULUT saat ini berjalan sesuai Standard Operating Procedure (SOP) Pelaksanaan Pemeriksaan. Perbedaan antara pelaksanaan audit di di ITPROV SULUT dengan prosedur pelaksanaan audit yang diatur dalam PKMA-APIP yaitu hanya pada waktu audit yang kadangkala berubah mengikuti kondisi atau situasi yang berkembang selama penugasan audit. Hal ini disebabkan karena perencanaan audit yang kurang optimal dan belum sepenuhnya sesuai dengan PKMA-APIP. Seperti yang sudah diuraikan sebelumnya dalam tahap perencanaan audit, ITPROV SULUT tidak menetapkan besaran resiko untuk setiap auditee dan tidak membuat peta audit sehingga frekuensi audit yang ditetapkan sama untuk seluruh SKPD.

Penyebab lainnya adalah kualitas kemampuan sebagian besar aparat pengawas dianggap belum memadai/memenuhi kualifikasi. Ketika sekretaris yang berperan menjalankan fungsi pengendali mutu melakukan review pada setiap hasil pekerjaan yang dilakukan oleh tim audit, masih didapati banyak kekurangan, ketidaksesuaian, kekurangan bukti sehingga harus diberi 
tambahan waktu yang mengakibatkan berubahnya waktu audit dari yang direncanakan. Dalam semua penugasan dan dalam semua tanggung jawabnya, setiap anggota harus melakukan upaya untuk mencapai tingkatan kompetensi yang akan meyakinkan bahwa kualitas jasa yang diberikan memenuhi tingkatan profesionalisme tinggi seperti diisyaratkan oleh prinsip etika (Mulyadi, 2002). Hal tersebut menegaskan bahwa, seharusnya ITPROV SULUT senantiasa mendorong aparat pengawasnya untuk selalu meningkatkan kompetensi dengan menyediakan pendidikan dan pelatihan yang berkelanjutan bagi aparat pengawasnya.

Penyebab yang lain yaitu kendala komunikasi antara aparat pengawas dengan auditee, misalnya permintaan data atau dokumen yang dibutuhkan untuk keperluan audit seringkali terlambat atau bahkan tidak dberikan oleh auditee, dan kadangkala pejabat-pejabat terkait yang akan diwawancara juga sulit untuk ditemui. Solusi untuk mengatasi kendala ini telah diatur dalam SOP Pelaksanaan Pemeriksaan ITPROV SULUT dimana jika tim audit kesulitan dalam menghimpun data/dokumen, tim audit dapat menyampaikan surat permintaan dokumen kepada auditee dengan tembusan Inspektur dan Wakil Gubernur. Jika dalam surat permintaan dokumen ketiga auditee masih belum memenuhinya maka tim audit meminta auditee untuk membuat surat pernyataan bahwa yang bersangkutan tidak bersedia diperiksa.

\subsection{Pelaporan Audit}

Penyusunan laporan merupakan tahap akhir dari pelaksanaan audit. Dalam Modul Penulisan Laporan Hasil Audit (BPKP, 2010) menjelaskan, laporan hasil audit dalam bentuk dokumen tertulis dapat berfungsi sebagai alat bukti dalam rangka penegakan hukum maupun dasar pelaksanaan tindak lanjut oleh manajemen lembaga pemerintah. Laporan hasil audit memuat temuan, kesimpulan, dan rekomendasi hasil audit dimaksudkan untuk mengkomunikasikan temuan sebagai sarana bagi auditee untuk melakukan perbaikan sesuai dengan rekomendasi yang diberikan, dan sebagai alat untuk pemantauan tindak lanjut. Laporan hasil audit yang dibuat haruslah mudah dimengerti oleh pengguna, memenuhi unsur kualitas laporan, dan didistribusikan kepada pihakpihak yang berwenang sesuai dengan ketentuan perundang-undangan.

Dari hasil analisi diketahui bahwa tahapan pelaporan audit yang dilaksanakan di ITPROV SULUT diatur dalam standar operational procedure (SOP) mengenai Penandatanganan LHP dan KKP yang ditetapkan oleh Inspektur. Perbedaan dalam tahap pelaporan audit yaitu tim audit tidak menyiapkan formulir kendali konsep laporan sebagai pengendalian dalam penyusunan LHP dan formulir review konsep laporan yang akan diisi oleh pengawas maupun Sekretaris saat melakukan review konsep LHP, serta formulir checklist finalisasi Laporan untuk memudahkan dalam melakukan proses koreksi. Penyebab adanya perbedaan tersebut karena dalam SOP yang ditetapkan oleh ITPROV SULUT tidak mengatur mengenai penyiapan formulir-formulir yang disebutkan diatas. Dalam Modul Penulisan Laporan Hasil Audit (BPKP, 2010), menjelaskan bahwa laporan harus didasarkan pada hasil pelaksanaan pengawasan audit yang didokumentasikan secara baik. Isi laporan harus sesuai dengan standar/pedoman pelaporan yang berlaku. Peraturan, standar, serta pedoman tersebut berfungsi sebagai ukuran mutu minimal bagi para pelaksana tugas dan fungsi pengawasan intern dalam melaksanakan tugas. Formulir-formulir yang disebutkan merupakan wujud pengendalian dalam proses penyusunan laporan hasil audit untuk menghasilkan LHP yang berkualitas yang mencakup sasaran dan ruang lingkup penugasan audit, kesimpulan, rekomendasi, serta rencana aksi. Hal ini menegaskan adalah penting dalam SOP penandatanganan LHP dan KKP ITPROV SULUT dilengkapi, dengan formulir pengendalian penyusunan laporan, formulir review konsep laporan, dan formulir checklist finalisasi laporan.

\subsection{Pemantauan Tindak Lanjut Hasil Audit}

Menurut Akmal (2006), tindak lanjut hasil pemeriksaan didefinisikan sebagai suatu proses

untuk menentukan kecukupan, keefektifan dan ketepatan waktu tindakan-tindakan koreksi yang dilakukan oleh manajemen terhadap rekomendasi dari temuan pemeriksaan yang dilaporkan. Pemantauan tindak lanjut hasil audit harus dilakukan agar auditee memahami dan memperbaiki 
kelemahan dan kesalahan yang ada sehingga mampu meningkatkan kinerja organisasinya. Standar Audit Intern Pemerintah Indonesia (SAIPI, 2013) seksi 4100 tentang Pemantauan tindak lanjut atas simpulan, fakta, dan rekomendasi audit menyatakan bahwa "Pemantauan dan penilaian tindak lanjut bertujuan untuk memastikan bahwa tindakan yang tepat telah dilaksanakan oleh auditi sesuai rekomendasi". APIP harus memantau pelaksanaan tindak lanjut yang dilakukan auditee untuk memastikan bahwa semua rekomendasi sudah dilaksanakan dengan tepat, sehingga keefektifan pelaksanaan audit bisa tercapai. Selain itu APIP juga harus memantau pelaksanaan tindak lanjut yang dilakukan auditee atas rekomendasi dari laporan hasil pemeriksaan oleh auditor external atau auditor lainnya.

Dari hasil analisis diketahui bahwa pemantauan tindak lanjut hasil audit yang dilaksanakan di ITPROV SULUT belum sepenuhnya sesuai dengan PKMA-APIP dimana prosedur pemantauan pelaksanaan tindak lanjut tidak didasarkan pada tingkat kesulitan, ketepatan waktu, pertimbangan resiko dan kerugian, kegiatan pemantauan hanya dilaksanakan 2 (dua) kali setiap tahun untuk kabupaten/kota dan untuk SKPD se-provinsi tidak ditetapkan berapa kali pemantauan dilaksanakan, pada setiap audit ulangan anggota tim audit melihat rekomendasi hasil laporan terdahulu apakah telah ditindaklanjuti hanya jika ada petunjuk dari pimpinan, formulir penyampaian temuan dan rencana tindak lanjut tidak dibuat. Daftar temuan dibuat berdasarkan Laporan Hasil Pemeriksaan (LHP) yang diterima sub bagian Evaluasi dan Pelaporan dalam bentuk hardcopy dan softcopy, verifikasi tindak lanjut yang disampaikan oleh auditee hanya dilaksanakan oleh penanggungjawab masing-masing wilayah/SKPD (staf sub evlap), tidak ada surat peringatan atau sanksi jika rekomendasi temuan belum ditindaklnjuti hingga batas waktu yang ditentukan. Penyebab adanya perbedaan tersebut karena ITPROV SULUT belum menyediakan prosedur sebagai acuan dan pengendalian dalam pemantauan tindak lanjut hasil audit dimana prosedur pemantauan pelaksanaan tindak lanjut yang didasarkan pada tingkat kesulitan, ketepatan waktu, pertimbangan resiko, dan kerugian. Prosedur tersebut selayaknya mengatur frekuensi pemantauan dilakukan, komposisi tim pemantauan, pemberian surat peringatan kepada auditee jika belum melaksanakan kewajiban tindak lanjutnya, serta menyiapkan formulir-formulir yang akan digunakan sebagai wujud pengendalian dalam pemantauan tindak lanjut hasil audit untuk menjamin keefektifan pelaksanaan pemantauan dan memastikan bahwa semua rekomendasi sudah dilaksanakan dengan tepat. Hiro (1997) dikutip oleh Hartono (2006), menyebutkan bahwa Prosedur untuk penjadwalan melaksanakan tindak lanjut harus didasarkan pada resiko dan kerugian yang terkait juga tingkat kesulitan dan perlunya ketepatan waktu dalam penerapan tindakan korektif. Manfaat audit intern tidak hanya terletak pada banyaknya fakta yang dilaporkan, namun juga terletak pada efektifitas tindak lanjut rekomendasi tersebut.

\subsection{Tata Usaha dan Sumber Daya Manusia}

Ketatausahaan merupakaan penunjang pelaksanaan pekerjaan audit mulai dari perencanaan audit sampai dengan pemantauan tindak lanjut hasil audit, oleh karena itu peran tata usaha tidak boleh diabaikan. Tata usaha sifatnya membantu atau menunjang bagi kelancaran pekerjaan pokok perkantoran/organisasi, sehingga tata usaha merupakan unsur administrasi dalam suatu kantor/organisasi (Saiman, 2002). Hal ini menegaskan bahwa ketatausahaan berjalan melalui prosedur dan kebijakan yang telah ditetapkan oleh organisasi. Selain memfasilitasi pelaksanaan audit, ketatausahaan juga terkait dengan pengelolaan sumber daya manusia, proses tata kearsipan yang mengatur surat-surat dan formulir-formulir yang digunakan dalam kegiatan audit sampai dengan proses pengarsipan dan penyimpanannya.

Sumber daya manusia adalah pilar penyangga utama sekaligus penggerak roda organisasi dalam usaha mewujudkan visi, misi, dan tujuannya (Susilo, 2007). Sumber daya manusia yang berkulitas akan menentukan kejayaan atau kegagalan dalam persaingan (Tambunan, 2003). Hal itu menegaskan bahwa sumber daya manusia juga merupakan hal yang penting dalam penyelenggaraan audit karena jika suatu organisasi sudah lengkap sarana prasarananya tapi tidak memiliki sumber daya manusia yang berkualitas, organisasi tersebut tidak dapat mencapai tujuannya ataupun 
diragukan kualitasnya. Agar tujuan pengelolaan unit APIP dapat dicapai, diperlukan kebijakan dan prosedur sebagai acuan bagi setiap pelaksanaan kegiatan.

Kegiatan tata usaha dan pengelolaan sumber daya manusia yang dilaksanakan sesuai dengan ukuran dan struktur organisasi serta kerumitan pekerjaan di ITPROV SULUT. Dalam menunjang pelaksanaan kegiatan ketatausahaan dan pengelolaan sumber daya manusia, ITPROV SULUT hanya menyediakan prosedur surat masuk/keluar. Jika mengacu pada Peraturan Gubernur Nomor 63 Tahun 2008 tentang Uraian Tugas Inspektorat Provinsi Sulawesi Utara, lingkup kerja sub bagian administrasi dan umum tidak hanya mengatur mengenai urusan surat menyurat saja. Tugas yang harus dilaksanakan oleh Sub Bagian Administrasi dan Umum, meliputi:

1) Mengkoordinasikan pelaksanaan administrasi dan umum;

2) Mengelola urusan tata usaha surat menyurat dan kearsipan;

3) Mengelola administrasi, inventarisasi, pengkajian dan analisis laporan;

4) Mengelola urusan kepegawaian, perlengkapan dan rumah tangga;

5) Megelola urusan administrasi keuangan;

6) Melaksanakan tugas lain yang diberikan oleh sekretaris.

Menurut Saiman (2002), agar kegiatan tata usaha dapat berjalan dengan baik dan maksimal, maka diperlukan suatu sistem tata usaha yang baik, dimana urutan pekerjaan tata usaha harus disusun dan dijalankan dengan teratur. Demikian halnya dalam Standar Audit Intern Pemerintah Indonesia (SAIPI, 2013) seksi 3040 paragraf 10 menjelaskan bahwa "Pimpinan APIP harus menyusun kebijakan dan prosedur untuk mengarahkan kegiatan audit intern. Kebijakan dan prosedur yang ditetapkan meliputi kebijakan dan prosedur pengelolaan kantor dan kebijakan dan prosedur pelaksanaan kegiatan audit intern".

\subsection{Kesimpulan}

\section{KESIMPULAN DAN SARAN}

Dari hasil penelitian diperoleh kesimpulan bahwa Implementasi Pedoman Kendali Mutu Audit-APIP pada Inspektorat Provinsi Sulawesi Utara belum optimal atau belum sepenuhnya sesuai. Hal ini disebabkan karena:

1) Perencanaan audit yang di laksanakan ITPROV SULUT belum sepenuhnya sesuai dengan PKMA-APIP, diantaranya:

a) Belum membuat atau menetapkan besaran resiko untuk setiap objek pemeriksaan yang akan menentukan seberapa dalam ataupun berapa kali dilaksanakan audit sesuai dengan resikonya, dan belum membuat peta audit yang didalamnya selain memuat besaran resiko juga memuat objek auditnya, tenaga auditornya, tenaga tata usaha, sarana dan prasarana, serta anggarannya;

b) Tidak membuat rencana audit jangka menengah lima tahun untuk memudahkan dalam penyusunan program kerja audit tahunan juga sebagai pengendalian pemeriksaan yang berulang-ulang, dan sebagai pengendalian dalam menyiapkan kesiapan/dukungan sumber daya diantaranya sumber daya manusia serta anggarannya yang dibutuhkan selama lima tahun kedepan;

c) PKPT yang disusun tidak menyajikan isi yang terperinci, hanya memuat jenis kegiatan audit beserta jadwal pelaksanaannya saja. Seharusnya PKPT yang disusun memuat objek pemeriksaan, resiko, waktu mulai hingga berakhirnya kegiatan audit, nama auditor yang bertugas dan jabatannya, anggaran atau biaya pelaksanaan kegiatan, jumlah hasil laporan yang akan diterbitkan, hingga unit yang akan melaksanakan, untuk menghindari tumpang tindih dan pemeriksaan berulang-ulang dan juga untuk memastikan ukuran bagi pencapaian kinerja ITPROV SULUT dalam lingkup tugas dan kewajibannya;

2) SDM yang dimiliki belum memenuhi kualifikasi dalam pemenuhan beban pekerjaan yang ada di ITPROV SULUT, dimana:

a) ITPROV SULUT belum memiliki pengendali teknis dan pengendali mutu;

b) Kurangnya sikap profesional yang dimiliki oleh sebagian ketua tim pada saat penugasan audit; 
c) Kompetensi atau kemampuan sumber daya manusia belum merata khususnya untuk aparat pengawas

3) Pemantauan tindak lanjut hasil audit yang dilakukan oleh unit yang melaksanakan fungsi evaluasi dan pelaporan belum maksimal karena belum disediakannya prosedur sebagai acuan dan pengendalian dalam pemantauan tindak lanjut hasil audit. Prosedur pelaksanaan kegiatan pemantauan tindak lanjut hasil audit hanya didasarkan pada auditee yang paling banyak temuan, kemudian tim yang melaksanakan pemantauan hanya berasal dari sub bagian evaluasi dan pelaporan, serta belum ada ketentuan yang jelas terhadap auditee yang sampai pada batas waktu yang ditentukan tidak memenuhi kewajibannya melaksanakan tindaklanjut atas rekomendasi yang diberikan;

4) Belum adanya pembagian tugas dan tanggungjawab dengan job description jelas pada unit yang melaksanakan fungsi tata usaha dan pengelolaan sumber daya manusia;

5) Prosedur yang disediakan oleh ITPROV SULUT dalam menunjang pelaksanaan tugas dan fungsinya belum memadai. Prosedur yang disediakan hanya SOP Pelaksanaan Pemeriksaan, SOP Penandatanganan LHP dan KKP, SOP Surat Masuk, SOP Surat Keluar, dan SOP Surat Tugas;

6) Belum dilaksanakannya pemantauan efektivitas pelaksanaan program dan kegiatan (peer-review) untuk memastikan dan menjamin bahwa audit yang dilaksanakan oleh Inspektorat telah memenuhi Standar Audit.

\subsection{Saran}

Dari hasil penelitian ini disarankan kepada Top Management di Inspektorat Provinsi Sulawesi Utara untuk mengoptimalkan implementasi Pedoman Kendali Mutu Audit-APIP dengan melakukan pengembangan prosedur pengendalian mutu dalam rangka meningkatkan kualitas fungsi pengawasannya. Tugiman (2006) menjelaskan, pimpinan audit internal harus menetapkan dan mengembangkan program pengendalian mutu untuk mengevaluasi berbagai kegiatan dari bagian audit internal. Senada dengan hal tersebut, dalam Standar Audit APIP paragraf 1170 menyatakan, APIP harus mengembangkan program dan mengendalikan kualitas mencakup seluruh aspek kegiatan audit di lingkungan APIP. Program tersebut dirancang untuk mendukung kegiatan audit APIP, memberikan nilai tambah dan meningkatkan kegiatan operasi organisasi serta memberikan jaminan bahwa kegiatan audit di lingkungan APIP sejalan dengan Standar Audit dan Kode Etik. Adapun langkah-langkah konkrit yang dapat dilakukan sebagai berikut:

1) Mengembangkan prosedur mulai dari tahap perencanaan audit sampai dengan pemantauan tindak lanjut hasil audit serta tata usaha dan pengelolaan sumber daya manusia sebagai panduan dalam pelaksanaan seluruh kegiatan di Inspektorat untuk memastikan dan memberi jaminan yang memadai bahwa audit yang dilaksanakan sesuai dengan Standar Audit;

2) Membentuk tim penilai resiko auditee yang bertanggungjawab dalam penentuan resiko auditee, dan pembuatan peta audit kemudian menetapkan besaran resiko untuk setiap objek pemeriksaan yang akan menentukan frekuensi atau berapa kali audit dilaksanakan sesuai dengan resikonya, serta membuat peta audit yang didalamnya selain memuat besaran resiko juga memuat objek auditnya, tenaga auditornya, tenaga tata usaha, sarana dan prasarana, serta anggarannya untuk mempermudah dalam menentukan frekuensi audit, fokus audit, dan kedalaman audit yang akan dilakukan terhadap setiap auditee, dan agar aparat pengawas akan lebih tepat dalam menentukan jumlah hari penugasan dan beban penugasan sesuai dengan besaran resiko yang dimiliki oleh masing-masing auditee sehingga membantu aparat pengawas dalam menyusun program kerja audit (PKA) nantinya;

3) Unit yang melaksanakan fungsi perencanaan di ITPROV SULUT membuat rencana audit jangka menengah lima tahunan, agar nantinya selain memudahkan dalam penyusunan program kerja audit tahunan juga sebagai pengendalian pemeriksaan yang berulang-ulang, dan sebagai pengendalian dalam menyiapkan kesiapan/dukungan sumber daya diantaranya sumber daya manusia serta anggarannya yang dibutuhkan selama lima tahun kedepan; 
4) PKPT yang disusun oleh unit yang melaksanakan fungsi perencanaan semestinya menyajikan isi yang lebih terperinci seperti PKAT dalam PKMA-APIP, tidak hanya memuat jadwal pelaksanaan kegiatan saja tetapi memuat objek pemeriksaan, resiko, waktu dimulai hingga berakhirnya kegiatan audit, nama auditor yang bertugas dan jabatannya, anggaran atau biaya pelaksanaan kegiatan, jumlah hasil laporan yang akan diterbitkan, hingga unit pelaksana kegiatannya karena selain untuk menghindari tumpang tindih dan pemeriksaan berulang-ulang juga untuk memastikan ukuran bagi pencapaian kinerja ITPROV SULUT dalam lingkup tugas dan kewajibannya;

5) Lebih maksimal dalam melakukan pengembangan pendidikan dan pelatihan berkelanjutan bagi para aparat pengawasnya dalam meningkatkan kompetensi serta keahlian yang dimiliki dengan harapan pelaksanaan audit menjadi lebih berkualitas baik melalui pendidikan dan pelatihan auditor, konferensi, seminar, kursus-kursus, program pelatihan di kantor sendiri, dan partisipasi dalam proyek penelitian yang memiliki substansi di bidang pengawasan;

6) Unit yang melaksanakan fungsi pelaporan melakukan pemantauan tindak lanjut hasil audit secara maksimal dengan jadwal dan tujuan kegiatan yang jelas untuk menjamin keefektifan pelaksanaan audit yang dilakukan Inspektorat maupun audit yang dilakukan oleh unit eksternal. Membentuk tim pemantau tindak lanjut hasil audit yang melibatkan auditor atau pengawas pemerintahan dari setiap wilayah yang melakukan tugas audit, serta senantiasa mendorong auditee untuk melaksanakan kewajibannya menindaklanjuti hasil audit beserta rekomendasinya;

7) Unit yang bertanggungjawab dalam melaksanakan fungsi tata usaha dan pengelolaan sumber daya manusia melakukan pembagian tugas dan tanggungjawab dengan job description yang jelas kepada stafnya masing-masing;

8) Melaksanakan pemantauan efektivitas pelaksanaan program (peer-review) untuk memastikan dan menjamin bahwa pelaksanaan kegiatan di Inspektorat telah memenuhi Standar Audit.

\section{DAFTAR PUSTAKA}

Akmal, 2006, Pemeriksaan Intern (Internal Audit), Penerbit PT. Indeks Kelompok Gramedia, Jakarta

Arens, Alvin. A., Randal J. Elder, and Mark S. Beasley, 2010. Auditing and assurances services: An Integrated approach, published by Pearson Education Inc, Upper Saddle River, New Jersey.

Arens, Alvin. A., Randal J. Elder, and Mark S. Beasley, 2015. Auditing dan Jasa Assurance: Pendekatan Terintegrasi, Terjemahan, Penerbit Erlangga, Jakarta.

Artherton, Tony, 2003. How to be better at Delegating and Coaching, Penerbit Gramedia, Jakarta.

Asosiasi Auditor Intern Pemerintah Indonesia (AAIPI), 2013, Standar Audit Intern Pemerintah Indonesia, Jakarta.

Boiman, Pipin Kurnia dan Raja A. S. Surya, 2013, Analisis Pengaruh Pelaksanaan Supervisi terhadap Kepuasan Kerja Auditor Internal Inspektorat Se-Provinsi Riau, Jurnal Ekonomi Volume 21.

Bogdan, Robert C. dan S.J. Taylor, 1975. Introduction to qualitative research Methods: A Phenomenological Approach to the Social Sciences. New York, John Willey \& Sons.

Budd, R. W., Thorp, R. K., \& Donohew, L (1967). Content analysis of communications. New York: Macmillan.

BPKP, 2009, Auditing, Edisi Kelima, Diklat Pembentukan Auditor Ahli.

BPKP, 2010, Modul Penulisan Laporan Hasil Audit, Edisi Kelima, Diklat Penjenjangan Ketua Tim.

BPKP, 2011, Modul Perencanaan Penugasan Audit, Edisi Keenam, Diklat Penjenjangan Auditor Madya.

Djam'an Satori, Aan Komariah, 2013. Metodologi Penelitian Kualitatif, Penerbit Alfabeta, Bandung. 
Hartono, Tri, 2006, Evaluasi Penyelesaian Tindak Lanjut Temuan Audit Sebagai Unsur Penilaian Kinerja Manajemen Kantor Cabang (Studi Kasus Pada Bank BTN), Tesis, Fakultas Ekonomi Universitas Diponegoro.

Horton, Paul B. dan Chester L. Hunt 1993, Sosiologi, Terjemahan, Penerbit Erlangga, Jakarta.

Hsieh Hsiu-Fang and Sarah E. Shannon. 2005. Three Approaches to Qualitative Content Analysis. Qualitative Health Reaserch, Vol.15 No.9, November 2005 1277-1278.

Konsorsium Organisasi Profesi Audit Internal, 2004, Standar Profesi Audit Internal, Jakarta.

Lukito Fauzi, Made Sudarma, M. Achsin, 2015. Penerapan Sistem Pengendalian Mutu (Spm) Dalam Meningkatkan Kualitas Audit. Jurnal Akuntansi Multiparadigma, Vol 6, No 1, April 2015.

Michael C. Jensen \& William H. Meckling, 1976, Theory of the Firm : Managerial Behavior, Agency Costs and Ownership Structure, Journal of Financial Economics Vol. 3 No. 4, October 1976.

Moleong, 2006. Metodologi Penelitian Kualitatif. Penerbit Rusda, Bandung.

Mulyadi, 2002, Auditing, Edisi ke-6, Penerbit Salemba Empat, Jakarta.

Pearce H. John A., and Richard B. Robinson, JR, 2000, Strategic Management: Formulation, Implementation, and Control. International Edition. McGraw-Hill, New York.

, Peraturan Gubernur Sulawesi Utara Nomor 8 Tahun 2008 tentang Organisasi dan Tata Kerja Inspektorat, Badan Perencanaan Pembangunan Daerah, Lembaga Teknis Daerah dan Lembaga Lain Provinsi Sulawesi Utara.

, Peraturan Gubernur Sulawesi Utara Nomor 68 Tahun 2008 tentang Uraian Tugas Inspektorat Provinsi Sulawesi Utara.

, Peraturan Menteri Negara Pendayagunaan Aparatur Negara dan Reformasi Birokrasi (PermenPAN dan RB) Nomor 19 Tahun 2009 tentang Pedoman Kendali Mutu Audit APIP.

Ritonga, H. Rahmansyah, 2013. Optimalisasi Audit Kinerja Instansi Pemerintah. Dipublikasikan pada http://sumut.kemenag.go.id tanggal 12 Juli 2103.

Sadono, Bayu Dewanto 2010. Analisis Pengendalian Mutu Audit pada Inspektorat Jenderal Kementerian Energi dan Sumber Daya Mineral (Studi Kasus: Penerapan Pedoman Kendali Mutu Audit-Aparat Pengawas Intern Pemerintah), Tesis, Magister Akuntansi Universitas Indonesia.

Saiman, 2002, Manajemen Sekretaris, Cetakan Pertama, Penerbit Ghalia Indo, Jakarta

STAN, 2007, Modul Program Pendidikan Non Gelar Auditor Sektor Publik "Manajemen Fungsi Audit Internal Sektor Publik", Jakarta.

, Standar Operational Procedure Pelaksanaan Pemeriksaan, 2015, Inspektorat Provinsi Sulawesi Utara.

, Standar Operational Procedure Penandatanganan LHP dan KKP, 2015, Inspektorat Provinsi Sulawesi Utara.

, Standar Operational Procedure Penerbitan Surat Tugas, 2015, Inspektorat Provinsi Sulawesi Utara.

, Standar Operational Procedure Pengadministrasian Surat Masuk, 2015, Inspektorat Provinsi Sulawesi Utara.

, Standar Operational Procedure Surat Keluar, 2015, Inspektorat Provinsi Sulawesi Utara.

Susilo, Martoyo, 2002, Manajemen Sumber Daya Manusia, BPFE, Yogyakarta.

Tambunan, Tulus, 2003, Perekonomian Indonesia, Penerbit Ghalia Indonesia, Jakarta.

Tugiman Hiro, 2006, Standar Profesional Audit Internal, Penerbit Kanisius, Yogyakarta.

Wahyudiono, Bambang. 2000. Evaluasi Atas Penerapan Sistem Pengendalian Mutu pada KAP H dan M, Tesis Program Pasca Sarjana Sekolah Tinggi Akuntansi Negara, Jakarta. 